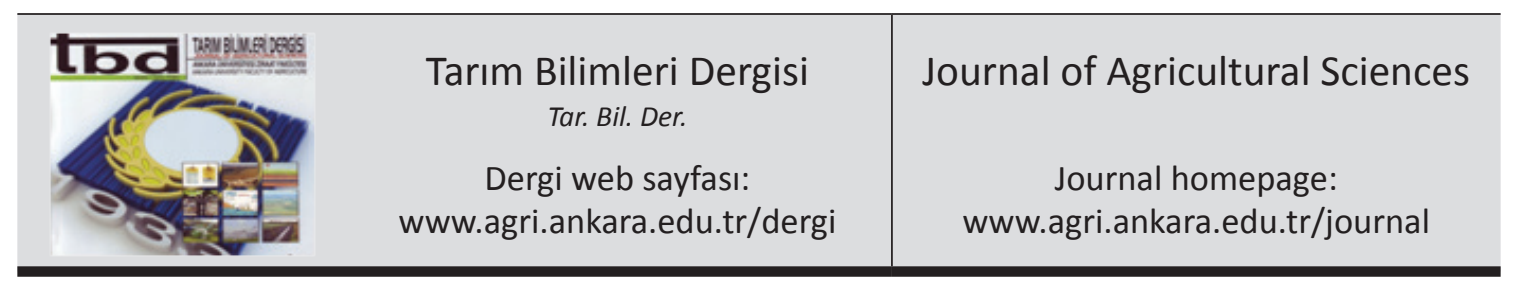

\title{
Sulanan ve Sulanmayan Koşullarda Yetiştirilen Nohut (Cicer arietinum L.)'un Gelişme Seyrinin Belirlenmesi
}

\author{
Nihal KAYAN ${ }^{a}$, Murat OLGUN , İmren KUTLU', Nazife Gözde AYTER ${ }^{\mathrm{a}}$, Nurdilek GÜLMEZOĞLU \\ ${ }^{a}$ Eskişehir Osmangazi Üniversitesi, Ziraat Fakültesi, Tarla Bitkileri Bölümü, 26160,Eskişehir, TÜRKIYE \\ ${ }^{\boldsymbol{b}}$ Eskişehir Osmangazi Üniversitesi, Ziraat Fakültesi, Toprak Bilimi ve Bitki Besleme Bölümü, 26160, Eskişehir, TÜRKIYE \\ ${ }^{c}$ Eskişehir Osmangazi Üniversitesi, Ziraat Fakültesi, 26160, Eskişehir, TÜRKIYE
}

\section{ESER BILGISII}

Araştırma Makalesi DOI: 10.1501/Tarimbil_0000001297

Sorumlu Yazar: Nihal KAYAN, E-posta: nkayan@ogu.edu.tr, Tel: +90 (222) 3242991

Geliş Tarihi: 14 Ocak 2014, Düzeltmelerin Gelişi: 10 Mart 2014, Kabul: 14 Mart 2014

\section{ÖZET}

Nohut üretimi, diğer bitkilerde de olduğu gibi kuraklık, tuzluluk, sıcaklık, çevre kirliliği ve besin maddelerinin noksanlığ ya da fazlalığı gibi çevresel stres faktörlerinden büyük ölçüde etkilenmektedir. Çalışmada; sulanan ve sulanmayan koşullarda yetiştirilen nohudun, farklı gelişme dönemlerinde bazı fizyolojik karakterlerinin ve azot alımının belirlenmesi amaçlanmıştır. Deneme tesadüf bloklarında bölünmüş parseller deneme desenine göre üç tekrarlamalı olarak kurulmuştur. Ana parsellere yetiştirme koşulları (sulanan ve sulanmayan) ve alt parsellere ise gelişme dönemleri (çiçeklenme öncesi, çiçeklenme, bakla doldurma ve hasat) yerleştirilmiştir. Çalışmada toprak üstü kütle, toprak altı kütle, ağırlık olarak kök/gövde oranı (\%), uzunluk olarak kök/gövde oranı (\%), yaprak alan indeksi, toprak üstü kuru madde ağırlığı, nispi büyüme oransal miktarı, net asimilasyon oranı, azot içeriği ve azot alımı özellikleri incelenmiştir. Araştırmada, nohudun generatif dönemine gelindiğinde, sıcaklığın yüksek olmasına karşın yeterince yağış alınamaması, bitkide kuraklık stresinin yaşanmasına ve buna bağlı olarak da toprak üstü kütlesinin düşmesine neden olmuştur. Buna rağmen kurak şartlarda kök gelişmesinin daha kuvvetli olduğu belirlenmiştir. Sonuçta; sulama olanağı varsa nohudun generatif dönemine yakın bir zamanda sulama yapılması bitki gelişimini olumlu etkileyecek ve bu da verim artışını sağlayabilecektir.

Anahtar Kelimeler: Nohut; Sulama; Fizyolojik karakterler; Azot alımı

\section{Determination Growth Progress of Chickpea (Cicer arietinum L.) Under Irrigation and Noirrigation Conditions}

\author{
ARTICLE INFO \\ Research Article \\ Corresponding Author: Nihal KAYAN, E-mail: nkayan@ogu.edu.tr, Tel: +90 (222) 3242991 \\ Received: 14 January 2014, Received in Revised Form: 10 March 2014, Accepted: 14 March 2014
}

\section{ABSTRACT}

Chickpea productivity is greatly affected by environmental stresses such as drought, salinity, temperature, environmental pollution and nutrient. The aim of this study, determination of some physiological charecters and nitrogen uptake 
at different developmental stages of chickpea (Cicer arietinum L.) under irrigation and noirrigation conditions. The experimental design was split plot with three replicas. Growth conditions (irrigation and noirrigation) were located in the main plots, growth stage (pre-flowering, flowering, pod setting and harvest time) in the subplots. Above-ground mass, below-ground mass, weight as root/stem rate (\%), lenght as root/stem rate (\%), leaf area index, above-ground dry weight, relative growth rate, net assimilation rate, nitrogen concentration and nitrogen uptake were investigated in this study. In the research, drought stress occured when the plants comes to generative stage due to increasing temperature and declining rainfall. Therefore above-ground mass was reduced. But root development was stronger under dry conditions. Irrigation in the generative stage will affect positively plant growth and yield in chickpea.

Keywords: Chickpea; Irrigation; Physiological characters; Nitrogen uptake

C Ankara Üniversitesi Ziraat Fakültesi

\section{Giriș}

Açlık ve yetersiz beslenme sorunu, nüfusun hızla arttığı dünyamızda her zaman önemli sorun olmuştur. Yemeklik tane baklagiller \% 18-31.6 arasında değişen protein oranları ile problemin çözümü için her zaman özel bir yere sahiptir (Şehirali 1988). Önemli bir protein kaynağı olan nohut özellikle hayvansal kaynaklardan yeterli proteinin sağlanamadığı ülkelerde dikkatleri üzerine toplamaktadır. Karbonhidrat, vitamin ve mineral maddelerce de zengin olan nohut yemeklik, çerezlik ve hayvan yemi olmak üzere çok yönlü bir tüketim alanına sahiptir (Karakullukçu \& Adak 2008). Kurağa ve düşük sıcaklığa dayanıklı olması ve toprak isteği bakımından da fazla seçici olmaması nohudun yetiştirilme olanağını artırmaktadır. Köklerinde ortak yaşam sürdüren Rhizobium bakterileri vasitasıyla havadaki elementel azottan faydalanabilmesi, yetiştiriciliğinin kolay ve gelişme döneminin kısa olması (Azkan 1989; Sepetoğlu 1994), nohudun tahıl nadas ekim nöbeti sisteminde yer almasına neden olmaktadır. Ülkemizde 2012 yılı verilerine göre yemeklik tane baklagiller içerisinde nohut 416.242 ha ekim alanı ve 535.000 ton üretim ile ilk sirada yer almaktadır (FAO 2012).

Kuraklık, tüm tarım alanlarını ve tarımsal ürünleri olumsuz etkileyen en önemli stres faktörlerinden biridir (Kalefetoğlu \& Ekmekçi 2005). Ekimden hasada kadar geçen sürede, bitkiler her dönemde kuraklık stresine maruz kalabilmektedirler (Güneş et al 2006). Ancak tarımsal üretime kuraklığın iki temel etkisi bulunmaktadır. Birincisi, istenilen bitki çıkışının sağlanamaması, ikincisi ise toprakta istenilenden daha az su bulunması nedeniyle gelişme ve verimde azalma olmasidır (Saxena et al 1993).

Kuraklık stresi altında kök gelişimi hızlanır ve kökün gövdeye oranı artar. Çünkü fotosentez ürünlerinin büyük bölümü kök gelişimi için köklere taşınır. Örneğin, çok yıllık kserofit bir bitki olan Alhagi camelorum'da toprak üstü aksamı bir kaç $\mathrm{cm}$ iken, kökler nemli bölgeye ulaşabilmek için 2-3 m'ye dek uzayabilmektedir (Öztürk \& Seçmen 1992). Yaprak büyümesi de kuraklık stresine karş1 oldukça hassastır. Kısa süreli kurak periyotlar dahi yaprak büyümesini yavaşlatmaktadır. Fotosentez kabiliyeti o bitkideki toplam yaprak alanı ve her yaprağın fotosentez aktivitesi ile belirlenir. Kuraklık stresi ile toplam yaprak alanı azalmakta ve dolayısıyla fotosentez yavaşlamaktadır (Çırak \& Esendal 2006).

Bitkilerin büyüme ve gelişmelerinin belirleyicisi olarak kabul edilen bazı fizyolojik karakterlerin belirlenmesi büyümenin tespitinde önemli yer tutmaktadır. Bu amaçla yapılan büyüme analizleri, bitki büyümesi ve bitki ile çevresi arasındaki etkileşimi açıklamaya yardımcı olmaktadır (Karadavut et al 2011). Bu konu ile ilgili yapilan çalışmalarda Jirali et al (1994) 6 farklı nohut genotipinde tane verimi ile toplam kuru madde ağırlığı ve yaprak alan indeksi arasında pozitif önemli ilişkilerin olduğunu bildirmişlerdir. Mahdavi et al (2004) çeltikte yaprak alan indeksi değerlerinin çiçeklenme döneminde diğer dönemlere göre daha yüksek, nispi büyüme oransal miktarının ise verim ile önemli düzeyde ilişkiye sahip olduğunu belirlemişlerdir. 
Tüm bitkilerde olduğu gibi nohutta da tane verimi çıkıştan olgunlaşmaya kadar, bitkinin büyüme ve gelişme sürecinde birçok morfolojik ya da fizyolojik etkinin fonksiyonları ve karşılıklı etkileşimleri ile oluşan, oldukça karmaşık kalıtımsal özelliğe sahiptir. Tane veriminin toplam büyümenin farklı devrelerinde söz konusu etkenlerin değişik oranda katkıları ile ortaya çıkan bir sonuç ürünü olduğu göz önüne alınırsa, başlıca temel amaçlardan birinin, yüksek verimli genotiplerin geliştirilmesinin oluşturduğu ıslah çalışmalarında, amaca ulaşabilmede bu faktörlerin verimi nasıl ve ne ölçüde etkilediğinin bilinmesi zorunlu olmaktadır (Altınbaş \& Sepetoğlu 1993).

Her ne kadar nohut kuru tarım bitkisi olarak bilinse de yağışın yetersiz olduğu dönemde suya iyi tepki veren bir bitkidir (Ullah et al 2002; Biçer et al 2004; Toğay et al 2005). Bu çalışmanın amacı hem sulanan hem de sulanmayan koşullarda nohut bitkisinde gelişme seyrini takip ederek kuraklıktan en fazla etkilendiği dönemi ortaya koymak ve bitkinin gelişiminde ortaya çıkan farklılıkları açıklamaktır.

\section{Çizelge 1- Araştırma yerine ilişkin iklim verileri}

Table 1-Climatic conditions on research area

\begin{tabular}{|c|c|c|c|c|c|c|}
\hline & \multicolumn{2}{|c|}{ Toplam yağış $(\mathrm{mm})$} & \multicolumn{2}{|c|}{ Ortalama sıcaklık $\left({ }^{\circ} \mathrm{C}\right)$} & \multicolumn{2}{|c|}{ Ortalama nispi nem (\%) } \\
\hline & $\begin{array}{c}\text { Uzun yullar } \\
(1990-2008)\end{array}$ & 2010 & $\begin{array}{c}\text { Uzun yillar } \\
\text { (1990-2008) }\end{array}$ & 2010 & $\begin{array}{c}\text { Uzun yillar } \\
(1990-2008)\end{array}$ & 2010 \\
\hline Ocak & 29.3 & 31.5 & -0.4 & 2.3 & 75.9 & 69.0 \\
\hline Şubat & 23.1 & 50.3 & 0.5 & 5.7 & 71.2 & 66.4 \\
\hline Mart & 27.6 & 27.7 & 4.7 & 6.7 & 64.6 & 59.3 \\
\hline Nisan & 43.1 & 41.2 & 9.6 & 10.2 & 62.7 & 61.2 \\
\hline Mayıs & 39.6 & 5.7 & 14.8 & 16.4 & 59.9 & 55.3 \\
\hline Haziran & 22.8 & 46.6 & 19.0 & 19.4 & 55.4 & 59.9 \\
\hline Temmuz & 12.7 & 14.3 & 21.9 & 23.3 & 51.9 & 59.8 \\
\hline Ağustos & 9.2 & 1.5 & 21.8 & 25.3 & 53.6 & 52.1 \\
\hline Eylül & 18.8 & 26.2 & 16.7 & 19.0 & 58.2 & 59.0 \\
\hline Ekim & 28.0 & 105.9 & 11.7 & 10.8 & 64.7 & 74.6 \\
\hline Kasim & 37.2 & 10.1 & 5.4 & 10.0 & 71.1 & 59.9 \\
\hline Aralık & 40.2 & 57.1 & 1.3 & 4.9 & 76.2 & 74.7 \\
\hline Toplam & 331.6 & 418.1 & & & & \\
\hline Ortalama & & & 10.6 & 12.8 & 63.8 & 62.6 \\
\hline
\end{tabular}

\section{Materyal ve Yöntem}

Araştırma, 2010 yılında Eskişehir Osmangazi Üniversitesi Ziraat Fakültesi deneme alanında yürütülmüştür. Deneme alanından alınan toprak örneklerinde yapılan analiz sonucunda, deneme alanının toprağı tınlı bünyeye sahip olup, $\mathrm{pH}$ nötr reaksiyonlu olarak belirlenmiştir. Organik madde orta düzeyde, tuzsuz ve orta düzeyde kireçlidir. Bitki besin maddelerinden potasyumca yüksek, fosforca yetersizdir. Araştırmanın yürütüldüğü bölgeye ilişkin uzun yıllar ile 2010 yılına ait sicaklık $\left({ }^{\circ} \mathrm{C}\right)$, yağış $(\mathrm{mm})$ ve nispi nem $(\%)$ değerleri Çizelge 1'de verilmiştir. Araştırma yılında, Mayıs ayı içerisinde uzun yıllar ortalamasından bir hayli düşük yağış düşerken, Haziran ayında daha fazla yağış gerçekleşmiştir.

Deneme tesadüf bloklarında bölünmüş parseller deneme desenine göre üç tekrarlamalı olarak kurulmuştur. Ana parsellere yetiştirme koşulları (sulanan ve sulanmayan) ve alt parsellere gelişme dönemleri (çiçeklenme öncesi, çiçeklenme, bakla doldurma ve hasat) yerleştirilmiştir. Hem sulanan hem de sulanmayan alanlarda, Gökçe nohut çeşidi 29 Mart 2010 tarihinde $30 \mathrm{~cm}$ sira aralığ 1 ve $6 \mathrm{~cm}$ 
sıra üzeri mesafelerde mibzer ile ekilmiş ve ekimle birlikte $3 \mathrm{~kg} \mathrm{da}^{-1} \mathrm{~N}$ ve $6 \mathrm{~kg} \mathrm{da}^{-1} \mathrm{P}_{2} \mathrm{O}_{5}$ gübrelemesi uygulanmıştır. Deneme 25 Temmuz 2010 tarihinde hasat edilmiş ve gerektikçe tüm parsellerde yabancı ot kontrolü amacıyla otlar elle alınmıştır. Azkan (1989) nohudun genel olarak kurak alanların bitkisi olmasına rağmen üç kez sulama ile veriminin önemli ölçüde artırılabileceğini bildirmektedir. $\mathrm{Bu}$ nedenle denemenin sulanmayan şartlarda yürütülen kısmında herhangi bir sulama yapılmazken, sulu şartlarda yürütülen kısmı 25 Nisan (çiçeklenme öncesi), 31 Mayıs (çiçeklenme başlangıcı döneminde) ve 30 Haziran (bakla doldurma devresi) tarihlerinde sulanmış ve her sulamadan sonra 9 adet bitki örneği alınmıştır. Son olarak hasat sırasında da belirtilen sayıda bitki örneği alınarak aşağıdaki yöntemlere göre ele alınan karakterler incelenmiştir.

Bitki örnekleri köklü olarak topraktan çıkartılmış ve kökler iyice yıkandıktan sonra kök ve gövde kısmı birbirinden ayrılmıştır. Bitki boyu ve kök uzunluğu ölçüldükten sonra uzunluk olarak kök/gövde oranı (\%) hesaplanmış, kök ve gövde k1smı $0.001 \mathrm{~g}$ duyarlı terazide tartıldıktan sonra yaş ağırlık olarak bakla ve taneleri ile birlikte toprak üstü kütle (TÜK) (g bitki $\left.{ }^{-1}\right)$ ve yaş ağırlık olarak toprak altı kütle (TAK) $\left(\mathrm{g}\right.$ bitki $\left.{ }^{-1}\right)$ ile ağırlık olarak kök/gövde oranı (\%) saptanmıştır. Yaprak alan indeksi (YAİ) Portable Area Meter (LICOR 3000 C, USA) ile ölçülmüştür. Bitkide kuru madde miktarının belirlenebilmesi için bitkiler $70{ }^{\circ} \mathrm{C}$ 'de sabit ağırlığa gelene kadar etüvde tutulmuştur (Perry \& Compton 1977). Kuruyan örnekler tartılarak ortalaması alınmış ve böylece bir bitkideki kuru madde miktarı bulunmuştur. Bu değerlerden toprak üstü kuru madde ağırlığı (TÜKMA) (g bitki $\left.{ }^{-1}\right)$, nispi büyüme oransal miktarı (NBO) $\left(\mathrm{g} \mathrm{g}^{-1}\right.$ gün $\left.^{-1}\right)$ ve net asimilasyon oranı (NAO) (mg m ${ }^{-2}$ gün$\left.^{-1}\right)$ aşağıda belirtilen şekilde hesaplanmıştır (Özalkan 2007).

$$
\begin{aligned}
& N B O=\frac{1}{W} \times \frac{d w}{d t} \\
& N A O=\frac{1}{L} \times \frac{d w}{d t}
\end{aligned}
$$

Burada; W, dönem başındaki bitki kuru ağırlığı; dw, iki ölçüm arasındaki kuru madde ağırlık artışı; dt, iki ölçüm arasında geçen zaman (gün); L, dönem başındaki toplam yaprak alan indeksidir $\left(\mathrm{m}^{2} \mathrm{~m}^{-2}\right)$.

Bitkiler vejetatif (çiçeklenme öncesi ve çiçeklenme) ve generatif dönemde (bakla doldurma ve hasat zamanında taneleriyle birlikte) her parselden 9 adet ve taneler ise hasat zamanında örneklenmiştir. Alınan örnekler etüvde $65^{\circ} \mathrm{C}$ 'de 48 saat kurutulduktan sonra kuru ağırlıkları alınarak öğütülüp, \% N miktarları Mikro Kjeldahl yöntemi ile belirlenmiştir (Kjeldahl 1883; Bremner 1960). Bitki örneklerinin azot alımı, bitkilerin kuru ağırlıkları ile $\mathrm{N}$ içerikleri $(\% \mathrm{~N})$ çarpılarak bir bitkinin topraktan kaldırdığı N miktarı (g N bitki $\left.{ }^{-1}\right)$ hesaplanmıştır.

Denemeden elde edilen veriler SPSS istatistik programı kullanılarak tesadüf bloklarında bölünmüş parseller deneme desenine göre varyans analizi ile değerlendirilmiş, uygulamalar arasında farklılığın önem düzeyini belirlemek amaciyla LSD testi uygulanmıştır (Düzgüneş et al 1983).

\section{Bulgular ve Tartışma}

Sulanan ve sulanmayan şartlarda yetiştirilen nohudun, çiçeklenme öncesi, çiçeklenme, bakla doldurma ve hasat dönemlerinde yetiştirme koşullarına verdiği tepkinin saptanması amacıyla yürütülen çalışmada, yapılan varyans analizi sonucunda toprak üstü kütle bakımından gelişme dönemleri arasındaki farklılık ile yetiştirme koşulları x gelişme dönemi interaksiyonu istatistiki olarak önemli bulunmuştur (Çizelge 2). En yüksek değer $199.43 \mathrm{~g} \mathrm{bitki}^{-1}$ ile bakla doldurma devresinde sulanmayan koşullarda belirlenirken, en düşük değer $5.17 \mathrm{~g} \mathrm{bitki}^{-1}$ ile çiçeklenme öncesi devrede sulanmayan koşullarda belirlenmiştir (Çizelge 3). Hem sulanan hem de sulanmayan koşullarda çiçeklenme dönemine kadar toprak üstü kütle ağırlığındaki artış az olurken, çiçeklenme döneminden sonra bakla doldurma dönemine kadar her iki yetiştirme koşulunda da hızlı bir artış olmuştur. Hasat dönemine yaklaşılırken sulanmayan koşullarda toprak üstü kuru madde ağırlığı azalırken, sulanan koşullarda bakla doldurma ve hasat dönemi arasında önemli bir artış ya da azalış görülmemiştir (Şekil 1). 
Çizelge 2- Sulanan ve sulanmayan koşullarda yetiştirilen nohutta farklı gelişme dönemlerine ait varyans analiz tablosu

Table 2- ANOVA results belong to different development stages of chickpea on irrigation and no irrigation conditions

\begin{tabular}{|c|c|c|c|c|c|c|c|}
\hline \multirow[b]{2}{*}{$V . K}$. & \multirow[b]{2}{*}{ S.D. } & \multicolumn{6}{|c|}{ Kareler ortalamas 1} \\
\hline & & $\begin{array}{c}T \ddot{U} K \\
\left(\mathrm{~g} b i t k i^{-1}\right)\end{array}$ & $\begin{array}{c}T A K \\
\left(\mathrm{~g} b i t k i^{-1}\right)\end{array}$ & $A O K G O(\%)$ & $\begin{array}{c}U O K G O \\
(\%)\end{array}$ & $Y A \dot{I}$ & $\begin{array}{l}\text { TÜKMA } \\
\left(\mathrm{g} b i t k i^{-1}\right)\end{array}$ \\
\hline Koşul & 1 & 3118.35 & 2.73 & 3.37 & $442.04 * *$ & $4.20 * *$ & 132.68 \\
\hline Hata- $_{1}$ & 2 & 3335.13 & 0.31 & 0.87 & 4.04 & 0.00 & 32.05 \\
\hline Dönem & 3 & $45889.12^{* *}$ & $40.67^{* *}$ & $141.82 * *$ & $403.04 * *$ & $77.74 * *$ & $7779.74 * *$ \\
\hline $\mathrm{A} \times \mathrm{B}$ & 3 & $3966.41 *$ & 1.00 & $5.15^{*}$ & $67.04 * *$ & $1.15 * *$ & $102.95 * *$ \\
\hline HATA & 12 & 877.91 & 1.78 & 0.90 & 8.62 & 0.07 & 7.46 \\
\hline Genel & 23 & 7491.34 & 6.65 & 19.86 & 86.59 & 10.52 & 1041.89 \\
\hline & & \multicolumn{6}{|c|}{ Kareler ortalamas 1} \\
\hline V.K. & S.D. & $\begin{array}{c}N B O M \\
\left(g g^{-1} g \ddot{u} n^{-1}\right)\end{array}$ & $\begin{array}{c}N A O \\
\left(m g m^{-2} g \ddot{u} n^{-1}\right)\end{array}$ & $\begin{array}{l}A \dot{I} \\
(\%)\end{array}$ & $\begin{array}{c}A A \\
\left(g N b i t k i^{-1}\right)\end{array}$ & & \\
\hline Koşul & 1 & 0.00 & 0.01 & 0.04 & 0.40 & & \\
\hline Hata- $_{1}$ & 2 & 0.00 & 9.76 & 0.00 & 0.10 & & \\
\hline Dönem & 3 & $0.14 * *$ & $501.75^{* *}$ & $2.60 * *$ & $2.27 * *$ & & \\
\hline $\mathrm{A} \times \mathrm{B}$ & 3 & $0.01 *$ & 33.27 & 0.07 & 0.11 & & \\
\hline HATA & 12 & 0.00 & 9.54 & 0.04 & 0.21 & & \\
\hline Genel & 23 & 0.02 & 70.97 & 0.37 & 0.45 & & \\
\hline
\end{tabular}

V.K., varyasyon kaynağı; S.D., serbestlik derecesi; TÜK, toprak üstü kütle; TAK, toprak altı kütle; AOKGO, ağırlık olarak kök/gövde oranı; UOKGO, uzunluk olarak kök/gövde oranı; YAİ, yaprak alan indeksi; TÜKMA, toprak üstü kuru madde ağırlığı; NBOM, nispi büyüme oransal miktarı; NAO, net asimilasyon oranı; Aİ, azot içeriği; AA, azot alımı

Haziran ayında düşen fazla miktardaki yă̆ış, bakla doldurma dönemine kadar bitkiler arasında toprak üstü kütle bakımından çok fazla farkın oluşmamasına neden olmuş olabilir (Çizelge 1). Ancak Temmuz ayında sıcaklığın artması fakat yeterince yağış alınamaması sonucu sulanmayan bitkilerde kuraklık stresi oluşmuş ve toprak üstü kütle ağırlığının düştüğü gözlenmiştir. $\mathrm{Bu}$ durum yetiştirme koşulları x gelişme dönemi interaksiyonuna da neden olmuştur. Kuraklık stresi altında bitkilerde yaş ağırlığın normal büyüyenlere göre daha yavaş arttığı, hatta stresin etkisiyle özellikle ilerleyen dönemlerde kuruma sonucu yaş ağırlıkta azalmaların olduğu görülmektedir (Fernández-Conde et al 1998; Alexieva et al 2001; Ashraf \& Iram 2005)
Toprak altı kütle bakımından sadece gelişme dönemleri arasında istatistiki anlamda farklılık gözlenirken (Çizelge 2); en yüksek değer $7.05 \mathrm{~g}$ bitki $^{-1}$ ile bakla doldurma devresinde, en düşük değer ise $0.82 \mathrm{~g} \mathrm{bitki}^{-1}$ ile çiçeklenme öncesi devrede belirlenmiştir (Çizelge 3). Sulanan ve sulanmayan koşullarda toprak altı kütle ağırlığı bakla doldurma dönemine kadar artış göstermiş ancak bakla doldurma ile hasat dönemi arasında her iki yetiştirme koşulunda da değerlerde düşüşler gözlenmiştir (Şekil 1). Sulanmayan koşullarda toprak altı kütle ağırlıkları sulanan şartlara oranla düşük olmuştur. Ashraf \& Iram (2005) kök yaş ve kuru ağırlıkları kuraklık stresi sonucu kontrol bitkilerine oranla azaldığını; Kanber (1977) sulama ile kök gelişiminin arttığını belirlemiştir. 
Ağırlık olarak kök/gövde oranı (\%) bakımından gelişme dönemleri arasındaki farklılık ile yetiştirme koşulları x gelişme dönemi interaksiyonu istatistiki olarak önemli çıkmıştır (Çizelge 2). En yüksek değer \% 14.66 ile çiçeklenme öncesi dönemde sulanan koşullarda belirlenirken, en düşük değer \% 2.00 ile hasat döneminde yine sulanan koşullarda belirlenmiştir (Çizelge 3). Çiçeklenme öncesi dönemde ağırlık olarak kök/gövde oranı sulanan koşullarda diğer dönemlere oranla daha yüksektir ve gelişme dönemi ilerledikçe kök/gövde oranının azaldığ1 görülmektedir (Şekil 1). Sulanmayan koşullarda da gelişme dönemi ilerledikçe ağırık olarak kök/gövde oranı giderek azalmıştır. Ancak hasat döneminde sulanmayan koşullarda kök/gövde oranının daha yüksek olması yetiştirme koşulları x
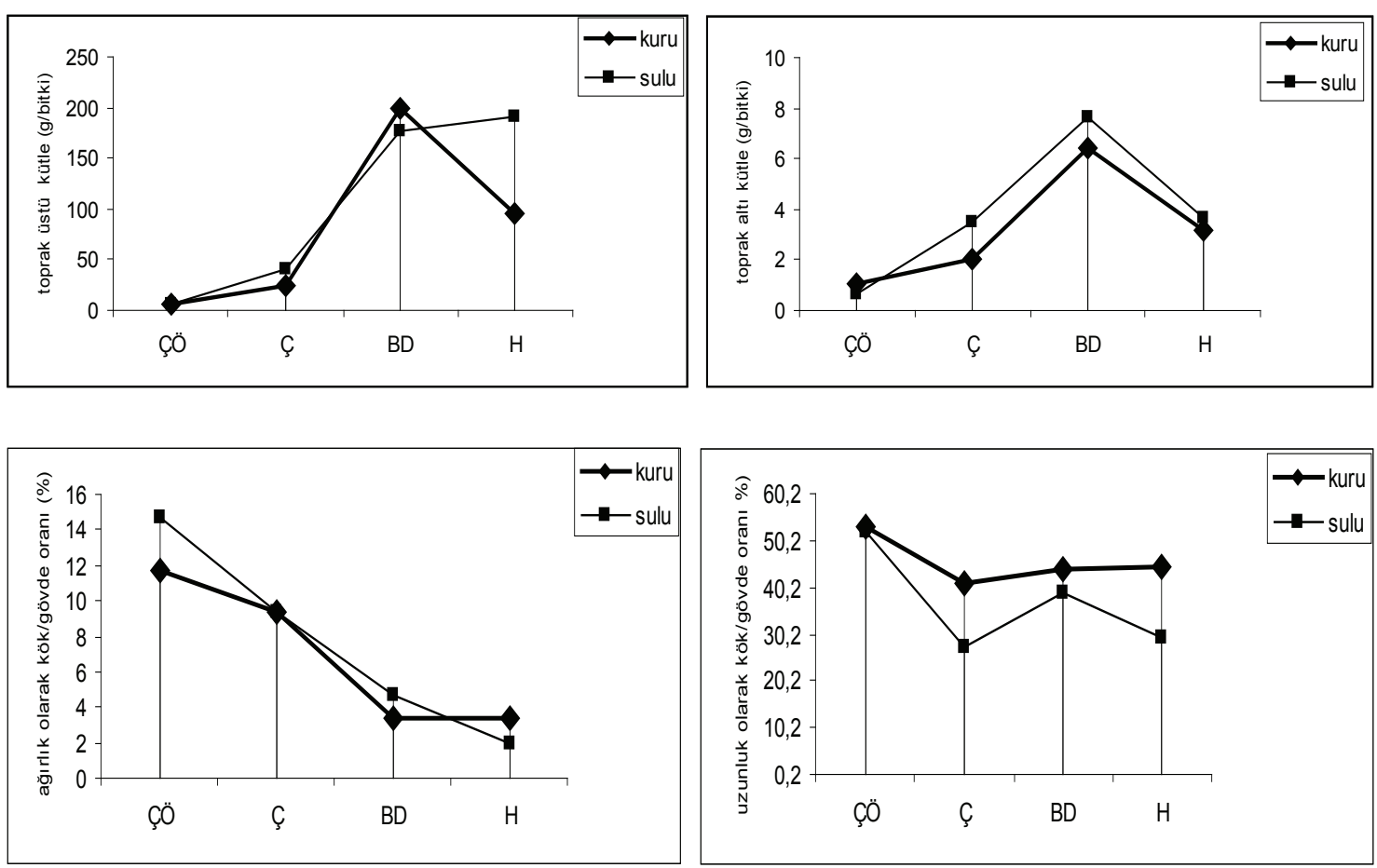

Şekil 1- Sulanan ve sulanmayan koşullarda yetiştirilen nohutta farklı gelişme dönemlerinde toprak üstü kütle (g bitki $\left.{ }^{-1}\right)$, toprak altı kütle (g bitki $\left.{ }^{-1}\right)$, ağırlık olarak kök/gövde oranı (\%), uzunluk olarak kök/gövde oranına (\%) ait değerler

Figure 1-Above-ground mass ( $g$ plant $\left.{ }^{1}\right)$, below-ground mass $\left(g\right.$ plant $\left.^{-1}\right)$, weight as root/stem rate (\%), length as root/stem rate (\%) at different development stages of chickpea on irrigation and no irrigation conditions 


\section{Çizelge 3- Nohut'ta incelenen özelliklere ilişkin ortalama değerler}

Table 3-Mean values of chickpea for investigated characters

\begin{tabular}{|c|c|c|c|c|c|}
\hline \multicolumn{6}{|c|}{ Gelişme dönemi } \\
\hline Koşul & $C ̧ \ddot{O}$ & $C$ & $B D$ & $H$ & Ortalama \\
\hline \multicolumn{6}{|c|}{ Toprak üstü kütle (g bitki $\left.{ }^{-1}\right)$} \\
\hline Sulanan & $6.68 \mathrm{c}$ & $40.01 \mathrm{c}$ & $177.36 \mathrm{a}$ & $191.98 \mathrm{a}$ & 104.01 \\
\hline Sulanmayan & $5.17 \mathrm{c}$ & $24.62 \mathrm{c}$ & $199.43 \mathrm{a}$ & $95.62 \mathrm{~b}$ & 81.21 \\
\hline Ortalama & 5.93 & 32.31 & 188.40 & 143.80 & LSD: 52.733 \\
\hline \multicolumn{6}{|c|}{ Toprak altı kütle $\left(\mathrm{g}\right.$ bitki $\left.{ }^{-1}\right)$} \\
\hline Sulanan & 0.62 & 3.47 & 7.64 & 3.64 & 3.84 \\
\hline Sulanmayan & 1.02 & 2.06 & 6.46 & 3.15 & 3.17 \\
\hline Ortalama & $0.82 \mathrm{c}$ & $2.76 \mathrm{bc}$ & $7.05 \mathrm{a}$ & $3.39 \mathrm{~b}$ & LSD: 2.353 \\
\hline \multicolumn{6}{|c|}{ Ağırlık olarak kök/gövde oranı (\%) } \\
\hline Sulanan & $14.66 \mathrm{a}$ & $9.33 \mathrm{c}$ & $4.66 \mathrm{~d}$ & $2.00 \mathrm{e}$ & 7.66 \\
\hline Sulanmayan & $11.66 \mathrm{~b}$ & $9.33 \mathrm{c}$ & $3.33 \mathrm{de}$ & $3.33 \mathrm{de}$ & 6.91 \\
\hline Ortalama & 13.16 & 9.33 & 4.00 & 2.66 & LSD: 1.691 \\
\hline \multicolumn{6}{|c|}{ Uzunluk olarak kök/gövde oranı (\%) } \\
\hline Sulanan & $52.33 \mathrm{a}$ & $27.66 \mathrm{c}$ & $39.00 \mathrm{~b}$ & $29.33 \mathrm{c}$ & 37.08 \\
\hline Sulanmayan & $53.33 \mathrm{a}$ & $41.00 \mathrm{~b}$ & $44.00 \mathrm{~b}$ & $44.33 \mathrm{~b}$ & 45.66 \\
\hline Ortalama & 52.83 & 34.33 & 41.50 & 36.83 & LSD: 7.323 \\
\hline \multicolumn{6}{|c|}{ Yaprak alan indeksi } \\
\hline Sulanan & $0.63 \mathrm{e}$ & $2.61 \mathrm{~d}$ & $9.43 \mathrm{a}$ & $6.76 \mathrm{bc}$ & 4.85 \\
\hline Sulanmayan & $0.55 \mathrm{f}$ & $2.04 \mathrm{~d}$ & $7.33 \mathrm{~b}$ & $6.16 \mathrm{c}$ & 4.02 \\
\hline Ortalama & 0.59 & 2.32 & 8.38 & 6.46 & LSD: 0.679 \\
\hline \multicolumn{6}{|c|}{ Toprak üstü kuru madde ăğırlığl $\left(g\right.$ bitki $\left.{ }^{-1}\right)$} \\
\hline Sulanan & $1.08 \mathrm{c}$ & $7.05 \mathrm{c}$ & $63.97 \mathrm{~b}$ & $75.93 \mathrm{a}$ & 37.01 \\
\hline Sulanmayan & $0.94 \mathrm{c}$ & $5.11 \mathrm{c}$ & $64.28 \mathrm{~b}$ & $58.89 \mathrm{~b}$ & 32.30 \\
\hline Ortalama & 1.01 & 6.08 & 64.12 & 67.41 & LSD: 6.810 \\
\hline \multicolumn{6}{|c|}{ Nispi büyüme oransal miktarl $\left(g g^{-1}\right.$ gün$\left.^{-1}\right)$} \\
\hline Sulanan & $0.29 \mathrm{ab}$ & $0.22 \mathrm{~b}$ & $0.02 \mathrm{c}$ & & 0.18 \\
\hline Sulanmayan & $0.24 \mathrm{~b}$ & $0.33 \mathrm{a}$ & $-0.007 \mathrm{c}$ & & 0.19 \\
\hline Ortalama & 0.26 & 0.28 & 0.00 & & LSD: 0.078 \\
\hline \multicolumn{6}{|c|}{ Net asimilasyon oranı $\left(\mathrm{mg} \mathrm{m}^{-2} \mathrm{gün}^{-1}\right)$} \\
\hline Sulanan & 12.93 & 16.21 & 2.25 & & 10.46 \\
\hline Sulanmayan & 10.51 & 21.68 & -0.68 & & 10.50 \\
\hline Ortalama & $11.72 \mathrm{~b}$ & $18.95 \mathrm{a}$ & $0.78 \mathrm{c}$ & & LSD: 5.984 \\
\hline \multicolumn{6}{|c|}{ Azot içeriği (\%) } \\
\hline Sulanan & 3.81 & 3.13 & 2.26 & 2.21 & 2.85 \\
\hline Sulanmayan & 3.50 & 2.91 & 2.40 & 2.29 & 2.77 \\
\hline Ortalama & $3.65 \mathrm{a}$ & $3.02 \mathrm{~b}$ & $2.33 \mathrm{c}$ & $2.25 \mathrm{c}$ & LSD: 0.350 \\
\hline \multicolumn{6}{|c|}{ Azot alımı $\left(\mathrm{g} N\right.$ bitki $\left.^{-1}\right)$} \\
\hline Sulanan & 0.23 & 0.59 & 1.72 & 1.57 & 1.03 \\
\hline Sulanmayan & 0.18 & 0.56 & 1.34 & 0.99 & 0.77 \\
\hline Ortalama & $0.20 \mathrm{c}$ & $0.57 \mathrm{bc}$ & $1.53 \mathrm{a}$ & $1.28 \mathrm{ab}$ & LSD: 0.806 \\
\hline \multicolumn{6}{|c|}{ Tanede azot içeriği (\%) } \\
\hline Sulanan & & & & 3.41 & \\
\hline Sulanmayan & & & & 3.27 & \\
\hline Ortalama & & & & 3.34 & \\
\hline
\end{tabular}

ÇÖ, çiçeklenme öncesi; Ç, çiçeklenme; BD, bakla doldurma; H, hasat 
olarak kök/gövde oranı çiçeklenme öncesi dönemde sulanan ve sulanmayan koşullarda birbirine çok yakın olmuş, çiçeklenme döneminde her iki yetiştirme koşulunda da kök/gövde oranı azalmış ancak bakla doldurma döneminde değerlerin tekrar yükseldiği görülmüştür. Hasat dönemine gelindiğinde sulanmayan koşullarda uzunluk olarak kök/gövde oranı çok fazla değişmezken, sulanan koşullarda oranın yeniden azaldığı görülmektedir. $\mathrm{Bu}$ azalış yetiştirme koşulları x gelişme dönemi interaksiyonunun önemli çıkmasının nedeni olmuştur. Gelişme devresi ilerledikçe, sulanmayan koşullarda sulanan koşullara oranla kök uzunluğu daha fazla, bitki boyu ise daha az olmuştur (Şekil 1). Kurak koşullara adapte olmuş bitkilerin neme ulaşabilmek amaciyla köklerini daha derine indirmeye çalışması sulanmayan ve sulanan koşullar arasındaki bu farkın temel nedeni olmuştur (Öztürk \& Seçmen 1992; Ceylan 1994; Kuşvuran 2010)

Yaprak alan indeksi bakımından yetiştirme koşulları ve gelişme dönemleri arasındaki farklılık ile yetiştirme koşulları x gelişme dönemi interaksiyonu istatistiki olarak önemli bulunmuştur (Çizelge 2). En yüksek değer 9.43 ile bakla doldurma döneminde sulanan koşullarda belirlenirken, en düşük değer 0.55 ile çiçeklenme öncesi dönemde sulanmayan koşullarda belirlenmiştir (Çizelge 3). Hem sulanan hem de sulanmayan koşullarda çiçeklenme öncesi dönemde yaprak alan indeksi değerleri birbirine çok yakın olmuş, gelişme dönemi ilerledikçe yaprak alan indeksi değerleri de artmış, hasat dönemine gelindiğinde ise her iki yetiştirme koşulunda da yaprak alan indeksi düşmüştür. Sulanan koşullarda hasat dönemindeki düşüşün fazla olması yetiştirme koşulları x gelişme dönemi interaksiyonunun da nedeni olmuştur. Sulanan koşullarda yaprak alanı indeksine ait değerler daha yüksektir (Şekil 2). Kurak koşullar altında gelişme ilerledikçe kuraklık stresinin etkisiyle yaprak alan indeksi azalmaktadır (Öztürk 1999; Tsuji et al 2003; Ashraf \& Iram 2005; Sankar et al 2008). Gelişmenin son döneminde kuruyarak yaprak kayıpları ortaya çıktığı için yaprak alan indeksi değeri azalmaktadır. Nitekim Aggrawal et al (1984) ve Anğın (2006)'ın yaprak alan indeksinin generatif döneme kadar arttığı fakat daha sonra azaldığı yönündeki bulguları bu fikri desteklemektedir.

Toprak üstü kuru madde ağırlığı bakımından gelişme dönemleri arasındaki farklılık ile yetiştirme koşulları x gelişme dönemi interaksiyonu istatistiki olarak önemli bulunmuştur (Çizelge 2). En yüksek değer $75.93 \mathrm{~g} \mathrm{bitki}^{-1}$ ile hasat döneminde sulanan koşullarda belirlenirken, en düşük değer $0.94 \mathrm{~g}$ bitki $^{-1}$ ile çiçeklenme öncesi dönemde sulanmayan koşullarda belirlenmiştir (Çizelge 3). Toprak üstü kuru madde ağırlığı, çiçeklenme öncesi, çiçeklenme ve bakla doldurma dönemlerinde sulanan ve sulanmayan koşullarda birbirine çok yakın çıkmıştır ve en fazla artış çiçeklenme ve bakla doldurma dönemleri arasında görülmüştür (Şekil 2). Bakla doldurma dönemine kadar bitkiler arasında toprak üstü kuru madde ağırlığı bakımından çok fazla farkın oluşmamasına Haziran ayında alınan fazla miktardaki yağış neden olmuş olabilir (Çizelge 1). Fakat Temmuz ayında sicaklığın artması ve yeterince yağış alınamaması sulanmayan bitkilerde kuraklık stresi oluşturmuştur. Kuraklık stresi bitkilerde toprak üstü kuru madde birikiminde hızlı bir azalmaya sebep olmaktadır (Galmes et al 2005; Sankar et al 2008). Dolayısiyla sulanmayan koşullardaki bitkilerde toprak üstü kuru madde ağırlığındaki azalmanın ana nedeni kuraklık stresi olmuştur. Bu durum yetiştirme koşulları x gelişme dönemi interaksiyonun da ana nedenidir.

Nispi büyüme oransal miktarı, birim zamanda, birim bitki kuru ağırlığı tarafindan biriktirilen kuru ağırlık miktarı veya diğer bir deyimle bitkideki fotosentez kazancının kuru ağırlık oluşturabilme etkinliğidir. Nispi büyüme oransal miktarı bakımından gelişme dönemleri arasındaki farklılık ile yetiştirme koşulları x gelişme dönemi interaksiyonu istatistiki olarak önemli bulunmuştur (Çizelge 2). En yüksek değer $0.33 \mathrm{~g} \mathrm{~g}^{-1}$ gün$^{-1}$ ile çiçeklenme döneminde sulanmayan koşullarda belirlenirken, en düşük değer -0.007 ile bakla doldurma döneminde yine sulanmayan koşullarda belirlenmiştir (Çizelge 3). Nispi büyüme oransal miktarı sulanmayan koşullarda çiçeklenme öncesi ve çiçeklenme dönemleri arasında artmış ancak çiçeklenme ve bakla doldurma dönemi arasında hızla düşmüştür. 

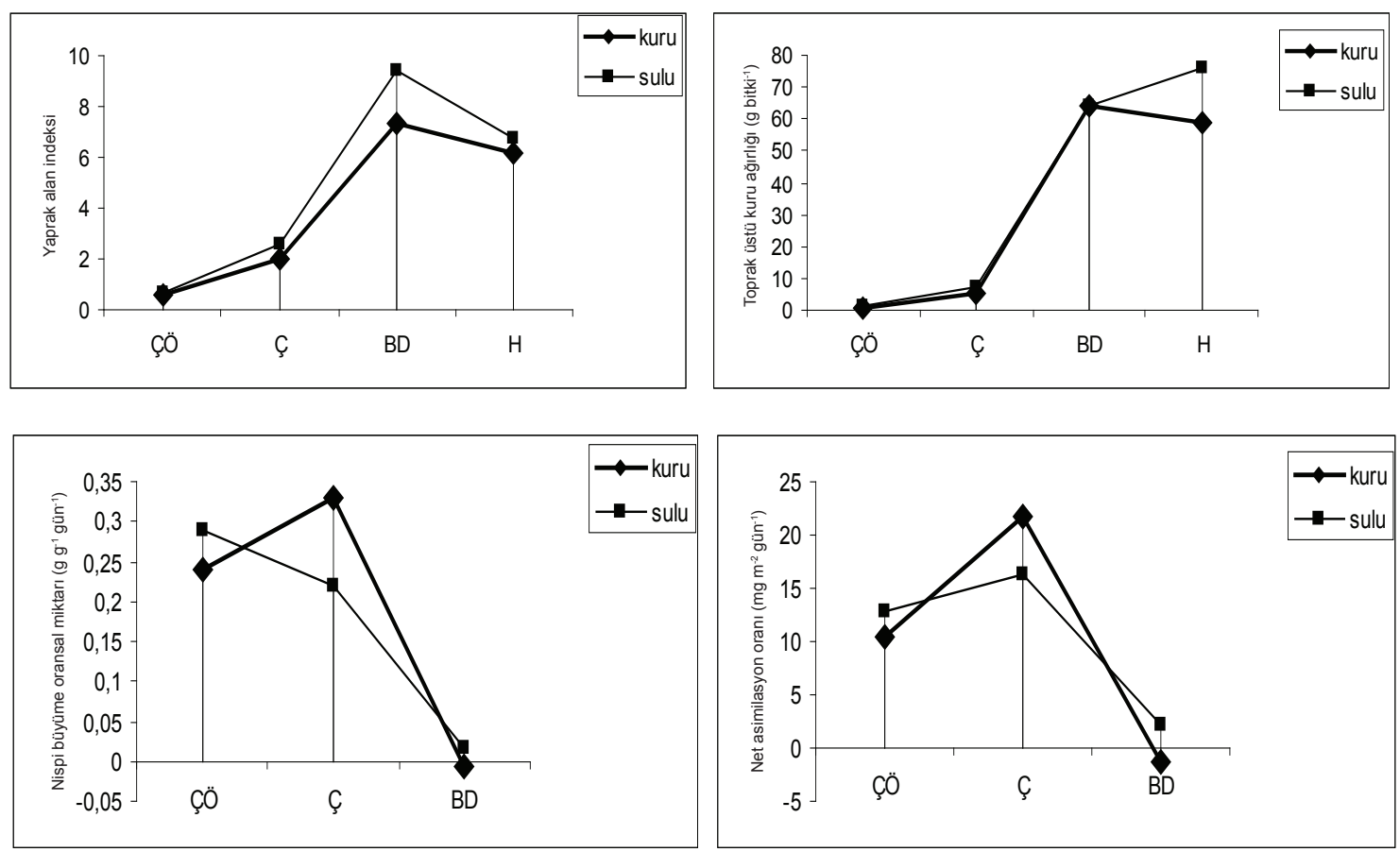

Şekil 2- Sulanan ve sulanmayan koşullarda yetiştirilen nohutta farklı gelişme dönemlerinde yaprak alan indeksi, toprak üstü kuru ağırlığı ( $\left.\mathrm{g} \mathrm{bitki}^{-1}\right)$, nispi büyüme oransal miktarı $\left(\mathrm{g} \mathrm{g}^{-1}\right.$ gün $\left.^{-1}\right)$ ve net asimilasyon oranına ( $\mathrm{mg} \mathrm{m}^{-2}$ gün $\left.^{-1}\right)$ ait değerler

Figure 2- Leaf area index, above-ground dry weight $\left(\mathrm{g} \mathrm{plant}^{-1}\right)$, relative growth rate $\left(\mathrm{g} \mathrm{g}^{-1}\right.$ day $\left.^{-1}\right)$, net assimilation rate $\left(\mathrm{mg} \mathrm{m}^{-2}\right.$ day-1) at different development stages of chickpea on irrigation and no irrigation conditions

$\mathrm{Bu}$ durum yetiştirme koşulları $\mathrm{x}$ gelişme dönemi interaksiyonunun önemli çıkmasına neden olmuştur. Sulanan koşullarda ise çiçeklenme öncesi dönem ile bakla doldurma dönemi arasında düzenli olarak nispi büyüme oransal miktarı düşüşü gözlenmiştir. Sadece çiçeklenme döneminde nispi büyüme oransal miktarı sulanmayan koşullarda sulanan koşullardan yüksek olmuştur (Şekil 2). Haziran ayında alınan fazla miktarda yağışa sulanmayan koşullarda yetişen bitkiler daha fazla tepki vermişlerdir ve çiçeklenme dönemine ait değerler sulanmayan koşullarda daha yüksek çıkmıştır (Çizelge 1). Son dönemde sulanmayan koşullarda ortaya çıkan azalmada ise yaprak kayıpları etkili olmuştur. Nogueira et al (1994) ve Özalkan (2007) bitkinin gelişme dönemi ilerledikçe nispi büyüme oransal miktarının azaldığını bildirmektedir.
Net asimilasyon oransal miktarı, birim zamanda, birim yaprak alanı tarafindan biriktirilen kuru ağırlık miktarı veya diğer bir deyimle yaprak alanının kuru ağırlık oluşturabilme yeteneğidir. Net asimilasyon oranı bakımından sadece gelişme dönemleri arasındaki farklılık istatistiki olarak önemli bulunmuş (Çizelge 2), en yüksek değer $18.95 \mathrm{mg} \mathrm{m}^{-2}$ gün $^{-1}$ ile çiçeklenme döneminde belirlenirken, en düşük değer $0.78 \mathrm{mg} \mathrm{m}^{-2}$ gün$^{-1}$ ile bakla doldurma döneminde saptanmıştır (Çizelge 3). Hem sulanan hem de sulanmayan koşullarda net asimilasyon oransal miktarı çiçeklenme dönemine kadar artmış, bakla doldurma dönemine doğru ise azalış göstermiştir. Çiçeklenme öncesi ve bakla doldurma döneminde sulanmayan koşullarda net asimilasyon oransal miktarı daha düşük değerler gösterirken, çiçeklenme döneminde sulanmayan 
koşullarda değerler daha yüksek çıkmıştır (Şekil 2). Haziran ayında alınan fazla yağış çiçeklenme döneminde sulanmayan koşullarda net asimilasyon oranının yüksek olmasına neden olmuştur (Çizelge 1). Nogueira et al (1994) ve Özalkan (2007) bitkinin gelişme dönemi ilerledikçe net asimilasyon oransal miktarının azaldığını bildirmektedir. İlerleyen gelişme dönemindeki azalmada ise kuraklık stresi ve bitki gelişme dönemi etkili olmuştur. Sankar et al (2008) ise kuraklık stresi altında net asimilasyon oranının azaldığını bildirmektedirler.

Azot içeriği ve azot alımı bakımından sadece gelişme dönemleri arasındaki farklılık istatistiki anlamda önemli bulunmuştur (Çizelge 2). Azot içeriği bakımından en yüksek değer \% 3.65 ile çiçeklenme öncesi dönemde belirlenirken en düşük değer \% 2.25 ile hasat döneminde belirlenmiştir. Azot alımı bakımından ise en yüksek değer $1.53 \mathrm{~g}$ $\mathrm{N}$ bitki $^{-1}$ ile bakla doldurma döneminde saptanırken

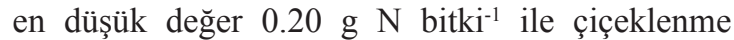
öncesi dönemde saptanmıştır (Çizelge 3). Bitkide azot içeriği bitkinin gelişme dönemi ilerledikçe azalmıştır (Şekil 3a) Gelişme ilerledikçe azot içeriğinin azalması bitkinin biomasının artması ile seyrelme etkisi göstermiştir. İlerleyen gelişmeye bağlı olarak bitkide yapısal maddeler (selüloz) artacağı için azot içeriği azalmaktadır (Geren et al 2003; Uzun et al 2012). Bitkilerin sulanmayan koşullarda tüm gelişme dönemlerindeki azot alımı sulanan şartlardan daha düşük belirlenmiştir. Her iki yetiştirme koşulunda da çiçeklenme döneminden sonra azot alımı değerleri artmıştır (Şekil 3b). Tanede azot içeriği sulanan koşullarda (\% 3.409) sulanmayan koşullara ( $\%$ 3.272) oranla daha yüksek belirlenmiştir. Bunun nedeni generatif devrede yüksek olan azot içeriğinin ve kuru madde miktarının sulanan koşullarda taneye daha fazla taşınmasıdır (Gan et al 2010; Yağmur \& Kaydan 2011).

\section{Sonuçlar}

Nohut her ne kadar kuru tarım bitkisi de olsa sulamaya olumlu tepki verdiği yapılan araştırmalarda ortaya konulmuştur. Araştırmanın yürütüldüğü yörede kış aylarında düşük evapotranspirasyon nedeniyle toprakta biriken su erken ilkbahar kuraklığını telafi ettiği için bu dönemdeki kuraklık nohut bitkisinin gelişmesi üzerine etkili olmamaktadır. Ancak generatif döneme gelindiğinde sıcaklığın artması ve yeterince yağış alınamaması sonucu nohutta kuraklık stresi yaşanmakta ve buna bağlı olarak toprak üstü kütlede artış hızı düşmektedir. Kurak koşullarda fotosentezin yavaşlaması, fotosentez ürünlerinin büyük bir bölümünün köklere taşınması ve ayrıca bitkilerin neme ulaşabilmek amacıyla köklerini daha derine indirmeleri sonucu nohut
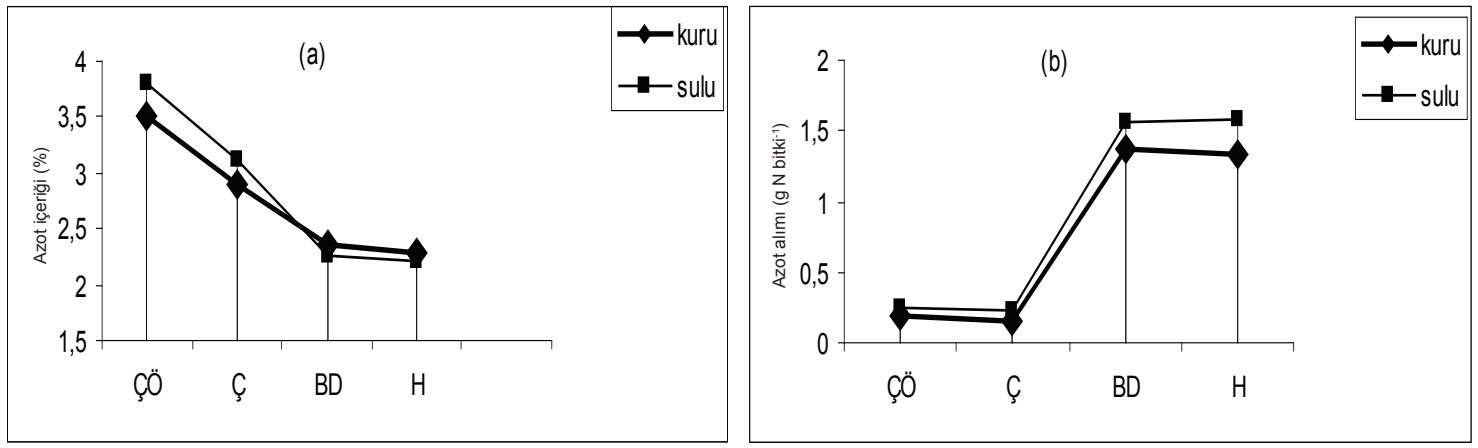

Şekil 3- Sulanan ve sulanmayan koşullarda yetiştirilen nohutta farklı gelişme dönemlerinde azot içeriği (\%) ve azot alımına ( $\mathrm{g} \mathrm{N}$ bitki $\left.^{-1}\right)$ ait değerler

Figure 3-Nitrogen concentration (\%) and nitrogen upteka $\left(g\right.$ Nplant $\left.^{-1}\right)$ at different development stages of chickpea on irrigation and no irrigation conditions 
bitkisinde kurak koşullar sulu koşullara oranla kök gelişmesi daha kuvvetli olmaktadır. Kurak alanların bitkisi olan nohutta, generatif dönemde ortaya çıkan kuraklık stresi yaprak kayıplarına bağlı olarak yaprak alanının azalmasına, dolayısıyla fotosentetik kazancın düşmesine neden olarak toprak üstü kütlede ve proteinde düşüşe neden olmaktadır. Bundan dolayı, sulama olanağı varsa generatif döneme yakın bir zamanda yapılacak sulama bitki gelişimini olumlu etkileyecek ve bu da verim artışı sağlayabilecektir.

\section{Kaynaklar}

Aggrawal P K, Khanna-Copra R \& Sinha S K (1984). Chages in leaf water potential in relation to growth and dry matter production. Indian Journal of Experimental Biology 22: 98-101

Alexieva V, Sergiev I, Mapelli S \& Karanov E (2001). The effect of drought ultraviolet radiation on growth and stres markers in pea and wheat. Plant, Cell and Environment 24(12): 1337-1344

Altınbaş M \& Sepetoğlu H (1993). Bir börülce (Vigna unguiculata L.) populasyonunda tane verimini etkileyen öğelerin belirlenmesi üzerine bir çalışma. Turkish Journal of Agricultural and Forestry 17(3): 775-794

Anğın N (2006). İkinci ürün mısırda farklı sulama zamanlarının fotosentetik su kullanım etkinliği ve bununla ilgili diğer yaprak özelliklerine etkisi. Yüksek lisans tezi, Çukurova Üniversitesi Fen bilimleri Enstitüsü (Basılmamış), Adana

Asraf M \& Iram A (2005). Drought stress induced changes in some organic substances in nodules and other plant parts of two potential legumes differing in salt tolerance. Flora 200: 535-546

Azkan N (1989). Yemeklik Tane Baklagiller. Uludağ Üniversitesi Ziraat Fakültesi Ders Notları. No: 40, Bursa

Biçer B T, Kalendar AN \& Şakar D (2004). The effect of irrigation on spring-sown chickpea. Journal of Agronomy 3(3): 154-158

Bremner J M (1960). Determination of Nitrogen in Soil by Kjeldahl Metod. Journal of Agronomic Science 55: $1-23$

Ceylan A (1994). Tarla Tarımı. Ege Üniversitesi Ziraat Fakültesi Yayınları, İzmir
Çırak C \& Esendal E (2006). Soyada kuraklık stresi. Ondokuz May1s Üniversitesi Ziraat Fakültesi Dergisi 21(2): 231-237

Düzgüneş O, Kesici T \& Gürbüz F (1983). İstatistik Metodları I. Ankara Üniversitesi Ziraat Fakültesi Yayınları. No: 861, Ankara.

FAO (2012). http://www.fao.org (Erişim tarihi: 10.11.2012)

Fernandez-Conde M E, De La Haba P, Gonzalez-Fontes A \& Maldonado J M (1998). Effects of drought (water stress) on growth and photosynthetic capacity of cotton (Gossypium hirsutum L.). 5th Internet World Congress for Biomedical Sciences, December, Canada, pp. 7-16

Galmes J, Cifre J, Medrano H \& Flexas J (2005). Modulation of relative growth rate and its components by water stress in Mediterranean species with different growth forms. Oecologia 145: 21-31

Gan Y, Campbell C A, Janzen H H, Reynald L L, Basnyat P \& McDonald C L (2010). Nitrojen accumulation in plant tissues and root and $\mathrm{N}$ mineralization under oilseeds, pulses and spring wheat. Plant Soil 332: 451-461

Geren H, Soya H \& Avcığlu R (2003). Yıllık italyan çimi ve tüylü fiğ karışımlarında farklı hasat zamanlarının bazı kalite özelliklerine etkisi üzerinde araştırmalar. Ege Üniversitesi Ziraat Fakültesi Dergisi 40(2): 17-24

Günes A, Çiçek N, İnal A, Alpaslan M, Eraslan F, Güneri E \& Güzelordu T (2006). Genotipic response of chickpea (Cicer arietinum L.) cultivars to drought stress implemented at pre- and postanthesis stages and its relations with nutrient uptake and efficiency. Plant Soil Environonment 52: 368-376

Jirali D I, Panchal Y C, Janagoudar B S \& Patil B C (1994). Studies on the growth pattern and yield in chickpea (Cicer arietinum L.) genotypes under receding soil moisture conditions. Indian Journal of Plant Physiology 37(4): 275-276

Kalefetoğlu T \& Ekmekçioğlu Y (2005). Bitkilerde kuraklı stresinin etkileri ve dayanıklılık mekanizması. Gazi Üniversitesi Fen Bilimleri Dergisi 18(4): 723-740

Kanber R (1977). Çukurova koşullarında bazı toprak serilerinin değişik kullanılabilir nem düzeylerinde yapılan sulamaların pamuğun verim ve su tüketimine etkileri üzerinde bir lizimetre araştırması (Doktora Tezi). Topraksu Araştırma Enstitüsü Müdürlüğü, Yayın No: 78, Tarsus, s. 1-151 
Karadavut U, Patla Ç, Tezel M \& Aksoyak Ş (2011). Yonca (Medicago sativa L.) bitkisinde bazı fizyolojik karakterlerin belirlenmesi. Süleyman Demirel Üniversitesi Ziraat Fakültesi Dergisi 6(2): 8-16

Karakullukçu E \& Adak M S (2008). Bazı nohut (Cicer arietinum L.) çeşitlerinin tuza toleranslarının belirlenmesi. Tarim Bilimleri Dergisi- Journal of Agricultural Sciences 14 (4): 313-319

Kjeldahl J (1883). Neve Methode Zur Bestimmong Des Sticksstoffs in Organishchen Körpern. Z. Anal. Chem 1883 (22): 360-382

Kuşvuran Ş (2010). Kavunlarda kuraklık ve tuzluluğa toleransın Fizyolojik mekanizmaları arasındaki bağlantılar. Doktora tezi, Çukurova Üniversitesi Fen Bilimleri Enstitüsü (Basılmamış), Adana

Mahdavi F, Esmail M A, Pirdashti H \& Fallah A (2004). Study on the physiological and morphological indices among the modern and old rice (Oriza sativa L.) genotypes. $4^{\text {th }}$ International Crop Science Congress, 26 September-01 October, Australia

Nogueira S S S, Nagai V, Braga N R, Do M, Novo C S S \& Camargo M B P (1994). Growth analysis of chickpea (Cicer arietinum L.). Scientia Agricola Piraciaba 51(3): 430-435

Özalkan Ç (2007). Nohut'ta bitki büyüme analizi ve bunun verimle ilişkisi. Yüksek Lisans Tezi, Ege Üniversitesi Fen Bilimleri Enstitüsü (Basılmamış), İzmir

Öztürk M A \& Seçmen Ö (1992). Bitki Ekolojisi. Ege Üniversitesi Fen Fakültesi Yayınları: 141, İzmir

Öztürk A (1999). Kuraklığın kışlık buğdayın gelişmesi ve verimine etkisi. Turkish Journal of Agriculture and Forestry 23: 531-540

Perry L J \& Compton W A (1977). Serial measures of dry matter accumulation and forage quality of leaves, stalks and ear of three corn hybrids. Agronomy Journal 69: 751-755

Sankar B, Abdul Jaleel C, Manıvannan P, K1shorekumar A, Somasundaram R \& Panneerselvan R (2008).
Relative efficacy of water use in five varieties of Abelmoschus esculentus (L.) Moench.under water limited conditions. Biointerfaces 62: 125-129

Saxena N P, Johansen C, Saxena M C \& Silim S N (1993). Selection for drought and salinity tolerance in coolseason food legumes. In: K.B. Singh and M.C. Saxena Eds. Breeding for stres tolerance in cool-season food legumes. United Kingdom, pp. 245-270

Sepetoglu H (1994). Yemeklik Dane Baklagiller. Ege Üniversitesi Ziraat Fakültesi Yayınları: 24, İzmir

Şehirali S (1988). Yemeklik Tane Baklagiller. Ankara Üniversitesi Ziraat Fakültesi Yayınlar1: 1089, Ders Kitab1: 314, Ankara

Toğay N, Toğay Y, Erman M, Doğan Y \& Çı̆̆ F (2005). Kuru ve sulu koşullarda farklı bitki sıklıklarının bazı nohut (Cicer arietinum L.) çeşitlerinde verim ve verim ögelerine etkileri. Tarım Bilimleri Dergisi-Journal of Agricultural Sciences 11(4): 417-421

Tsuj1 W, Alı M.E.K, Inanaga S \& Sugımoto Y (2003). Growth and gas exchange of three sorghum cultivars under drought stres. Biomedical and Life Sciences 46 (4): 583-587

Ullah A, Bakht J, Shafi M, Shah W A \& Islam Z (2002). Effect of various irrigation levels on different chickpea varieties. Asian Journal of Plant Science 1(4): 355-357

Uzun A, Gün H \& Açıkgöz E (2012). Farklı gelişme dönemlerinde biçilen bazı yem bezelyesi (Pisum sativum L.) çeşitlerinin ot, tohum ve ham protein verimlerinin belirlenmesi. Uludağ Üniversitesi Ziraat Fakültesi Dergisi 26(1): 27-38

Yağmur M \& Kaydan D (2011). Plant growth and protein ratio of spring sown chickpea with various combinations of rhizobium inoculation, nitrogen fertilizer and irrigation under rainfed condition. African Journal of Agricultural Research 6(12): 2648-2654 